\title{
JOOX Application as a Media to Improve Students' Pronunciation
}

\author{
Author \\ Ari Astutik, Nur Hidayat, Indah Rosyida \\ Correspondence \\ Universitas Wijaya Putra Surabaya, STKIP Bina Insan Mandiri Surabaya, Universitas Wijaya Putra Surabaya \\ ari.astutik08@gmail.com,nurhidayat@stkipbim.ac.id, shantyduwila@gmail.com
}

\begin{abstract}
:
The newest students in university often have difficulty with pronunciation in English. This article is based on the study on students' pronunciation of Wijaya putra Surabaya University in the first semester. The purpose of this study is to improve the sudents' pronunciation achievement by using Joox as a media. The subjects were 15 students of wijaya Putra University in the first semester. The data of the study were collected by interview, observation and test. The design of this study was classroom action research which consist of planning, acting, observing and reflecting. In analyzing the data, researcher compared the result of all instruments (interview, observation and test) and concluded it. The result showed that Jooox had positive effect to improve students' pronunciation achievement.
\end{abstract}

Keywords: pronunciation, media, joox.

\section{Introduction}

The phenomenon of dependence on technology as a lifestyle among students certainly has positive and negative effects. With technology they can access various informations and interact with anyone, anywhere and anytime. On the other hand, technology can take a few hours of their time when 'chatting' or when using other applications. This tends to make them divert time which should be used for other activities that are more useful like learning.

Against this phenomenon, technology can actually be used as an alternative to improve students' ability especially in English. This is related to efforts to increase students' enthusiasm for learning towards optimal learning outcomes.

The use of media in teaching learning will give positive effect to teaching learning itself (Arsyad, 2007; Hidayat, 2018). Media becomes a good tool in delivering materials in the classroom. JOOX is one of application that can be used as a media in teaching learning English. It provides facilities that can be used in to improve students' English such as: English songs with the lyrics, Social circle, offline play and timer. Those facilities give benefit to the user especially for English teachers \& students who want to improve their pronunciation easily.
Received: 07 Januari 2019. Accepted: 23 Januari 2019

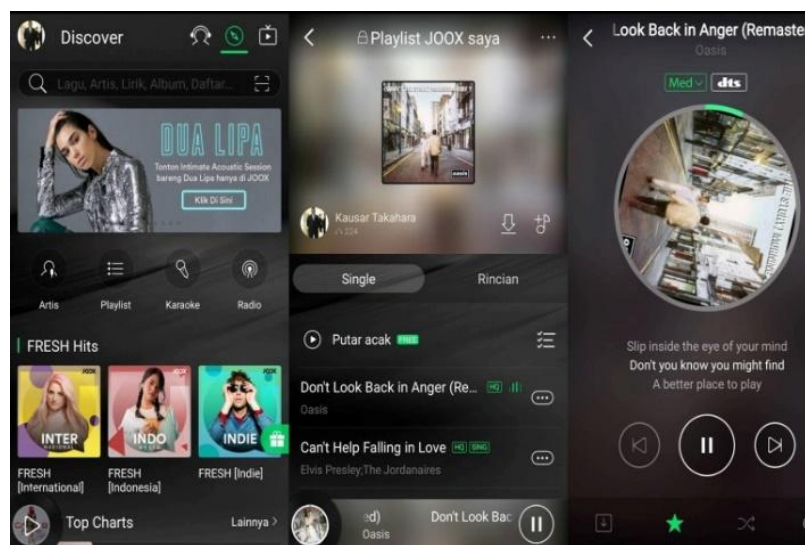

Figure 1. The Display of Joox Application

Teaching using a song in learning pronunciation will certainly provide more benefits and pleasure (Griffe, 2001; Harmer, 2000; Kanel, 2000; Lo and Li, 1998; Millington, 2011; Richard, 1993; Shen, 2009; Ulate, 2008). Cakir (1999) explains that Music is one of good media that help the students enhance their language acquisition. The use of song in teaching learning process influences the athmosphere in the classroom, and the teacher's and students' feeling to be better (De Porter, 2006; Lappi, 2009; Paul, 2003). It also motivates students in the process of teaching learning (Qurt, 2013).

\section{Method}

The research design of this study was a classroom action research because it was in line with the objective of the study which investigated the use of Joox in teaching English pronunciation. 
The subjects of this study were 15 students ( 3 male \& 12 female) of Wijaya Putra University in the first semester.

\section{Action Research Procedure}

\section{a. Planning}

In this step, the researcher prepared teaching media, lesson plan, and all teaching aids in doing classroom action research, strating from the first until the end of the process.

\section{b. Acting}

In this step, the pronunciation lecturer applied the Joox as a media in teaching pronunciation. Before doing the treatment, the researcher asked to the students to install Joox application to their mobile phone. The researcher also explained about the procedure in using Joox to them. In the treatment, the lecturer took five songs from the Joox that related to pronunciation topic that had been prepared by her. The application of treatment is done in the process of teaching learning in the classrom. In the first cycle and second, the researcher did the treatment in three meetings.

\section{c. Observation}

In this step, the researcher observed the implementation of JOOX in the teaching pronunciation, the suitability between planning and teaching implementation, students' pronunciation progress in every meeting as well as from the quizzes and tests.

\section{d. Reflection}

Reflection was done after the researcher did the action and observation. It was done to evaluate the result of students' improvement and decide to continue the second cycle or not.

\section{Research Instrument}

In this study, the researcher used questionnaires, interview, observation and test (pre-test and post-test) as research instruments. The interview and observation were done by the researcher, while the test was done by the lecturer. Pre-test was delivered before the lecturer gave the treatment, while the post test was delivered after lecturer gave the treatment. The questionnaires were given to the students after they got the treatment. The questionnaires of this study were modified from Hidayat's articles (2016).

\section{Data Analysis}

In analyzing the data, the researcher used qualitative and quantitative technique. The researcher also assigned the criteria of success. There were two criteria of success: the students' achievements were improved and the students' average riched 80 .

\section{Findings and Discussion}

From the interview, the researcher found that the main problem the class was the students' ability. It was influenced by the students' background, students' business, students' environtment and students' motivation. Most of them were workers. Sometomes, they felt difficult in managing their time in learning and time and working. Therefore, they needed portable media or application that can be used any where without bothering their work.

In this Research, the researcher did two cycles. The first and second cycles consisted of three meetings. The treatment was done during teaching learning process. The researcher accompanied by another observer of the English lecturer when she apllied the Joox in the class.

After giving the treatment the researcher did the post-test to know the students' improvement. The exercises constructed by the reasearcher and the lecturer. The result of pre-test, the first cycle and the second cycle can be seen on the Table. 1 .

Table 1. The result of pre-test, the first cycle and the second cycle.

\begin{tabular}{|c|c|c|c|c|}
\hline \multirow{2}{*}{ No } & \multirow{2}{*}{ Students' Name } & \multicolumn{3}{|c|}{ Students' Score } \\
\hline & & Pre-Test & Cycle 1 & Cycle 2 \\
\hline 1 & A.L & 52 & 68 & 86 \\
\hline 2 & A.S.R & 56 & 70 & 88 \\
\hline 3 & G.A & 58 & 74 & 88 \\
\hline 4 & H.A & 56 & 78 & 92 \\
\hline 5 & S.T & 60 & 82 & 98 \\
\hline 6 & V. C. L & 60 & 78 & 88 \\
\hline 7 & A.W & 64 & 74 & 96 \\
\hline 8 & D. D & 50 & 70 & 86 \\
\hline 9 & I.A.F & 64 & 76 & 90 \\
\hline 10 & N.S.F & 70 & 84 & 98 \\
\hline 11 & A.N.D & 68 & 78 & 88 \\
\hline 12 & A.A & 60 & 80 & 90 \\
\hline 13 & F.D.L & 66 & 80 & 92 \\
\hline 14 & D.S.B & 62 & 80 & 94 \\
\hline 15 & R.H.H & 54 & 76 & 86 \\
\hline & Total & 900 & 1148 & 1358 \\
\hline & Average & 60 & 76,53 & 90,67 \\
\hline
\end{tabular}

The table above showed that the students' average of pre-test scores (pronunciation test) were 60; the average of first cycle were 76,53 and the average of second cycle were 90,67 . The result 
showed that the students' scores of pre-tests and the first cycle were below the passing grade. It meant that the students' pronunciation achievement have improved and it also fulfilled the first criteria of success. In the other hand, the students' average of the first cycle were 76,53. It showed that the second criteria of success had not been achieved so that the researcher needed to do the second cycle.

Before continuing the second cycle the researcher analyzed and evaluated the implementation of Joox. The result of the use of Joox in the first cycle was good. It is showed by the improvement of students' average that increased from 60 to 76,53. In the first cycle, the treatment only gave in the process of teaching learning in the classroom. From the explanation above, the researcher thought that it will be more effective when the students use Joox not only in the classroom but also outside the classroom. Therefore, the researcher modified the treatment for the second cycle by adding the duration of Joox use in the class and outside the class. The researcher asked them to use Joox in the free time outside the classroom and to note it as a proof that the students did it.

After doing the second cycle, the researcher did the second test to now the development of students' achievement. The result of post-test showed that the students' average in second cycle were 90,7 . The students' score increased and the average students' score higher than 80. It meant first and the second criteria of success had been achieved.

Table. 2. The Result of student's Questionnaires

\begin{tabular}{lcc}
\multicolumn{1}{c}{ Questions } & \multicolumn{2}{c}{ Student's answer } \\
\cline { 2 - 3 } you like Joox application that is & 15 & 0 \\
\hline $\begin{array}{l}\text { Do you } \\
\text { applied by your lecturer? }\end{array}$ & & 0 \\
$\begin{array}{l}\text { Does that application make you happy in } \\
\text { joining the pronunciation class? }\end{array}$ & 15 & 0 \\
$\begin{array}{l}\text { Does that application make you enjoy the } \\
\text { teaching learning process? }\end{array}$ & 15 & 0 \\
$\begin{array}{l}\text { Do you think that application motivate you } \\
\text { in learning pronunciation? }\end{array}$ & 15 & 2 \\
$\begin{array}{l}\text { Does that application help you to } \\
\text { memorize English vocabulary? }\end{array}$ & 13 & 0 \\
$\begin{array}{l}\text { Does that application help you to } \\
\text { understand Pronunciation? }\end{array}$ & 15 & 0 \\
$\begin{array}{l}\text { Do you think that sing songs help you to } \\
\text { memorize the pronunciation of words } \\
\text { easier? }\end{array}$ & 15 & \\
$\begin{array}{l}\text { Do you think that application is good to be } \\
\text { used outside the classroom? }\end{array}$ & 15 & 0 \\
$\begin{array}{l}\text { Do you think that sing songs are able to } \\
\text { improve your pronunciation ability? }\end{array}$ & 15 & 0 \\
\hline
\end{tabular}

The questionnaires above indicated that most of the students were motivated when the lecturer use Joox in Pronunciation class. They thought that it could help them in memorizing and understanding words and make them easier in pronucing them.

All the data above showed that all criteria of success were achieved. It meant that implementation of Joox can improve students' pronunciation achievement. It was corresponding with the previous researchers' opinion that the use of songs gave positif effects and benefits to the students' pronunciation.

\section{Conclusion}

From all the result above can be concluded that the use of Joox in teaching pronunciation is able to improve students' achievement. It also motivates the students to learn pronunciation and help them memorize and comprehend the words especially in pronunciation class.

\section{References}

Arsyad, A. 2007. Media Pembelajaran. Jakarta: PT. Rajagrafindo Persada.

Cakir, A. (1999). Musical activities for young learners of EFL. The Internet TESL Journal, 5

De Porter, Bobbie; Mark R.; dan Sarah S.N. (2006). Quantum Teaching Mempraktekkan Quantum Learning di Ruang-ruang Kelas. Bandung: Mizan Pustaka.

Griffe, D.T. 2001. Songs in Action. Hertfordshire: Prentice Hall International.

Harmer, J. 2000. The Practice of English language Teaching. London: Longman Group Ltd.

Lo, R., \& Li, H. (1998). Songs enhance learner involvement. English Teaching Forum, 36, 8$11,21$.

Millington, N. T. (2011). Using songs effectively to teach English to young learners. Language Education in Asia, 2(1), 134-141.

Hidayat, N. (2016). November 2016, 2016 Published: 19. Journal of Educators Society, 1(October), 95-104 https://doi.org/10.21070/jees.v1i2.446

Hidayat, N. (2018). Training Media Learning for Teachers of MI Citra Taman Siswa. Kontribusia, 55-57

Shen, C. (2009). Using English songs: an enjoyable and effective approach to ELT. English 
Language Teaching, 2(1).

Ulate, N. V. (2008). Using songs to improve EFL students' pronunciation. Congress International de Lillgiiística Aplicada, (93108). Costa Rica. 